\title{
QUANTITATIVE NON-DESTRUCTIVE NEUTRON ACTIVATION ANALYSIS OF SILVER IN COINS
}

\author{
BY A. A. GORDUS
}

Department of Chemistry, The University of Michigan, Ann Arbor, Michigan 48104

\section{INTRODUCTION}

Historians concerned with the ancient and medieval' worlds have tended to rely solely on written evidence, neglecting the most abundant historical artifacts available-coins. When turning to numismatic evidence, the historian generally concerns himself only with the enscribed dates and names of rulers. However, the sheer quantity of coins available provides an opportunity for the historian, and particularly the economic historian, to study the coins for what they are-a money. In many cases coins are the most important, if not the only source of information about significant monetary and economic changes. Thus, the historian must go beyond the mere surface details of the coins, as valuable as these may be to him, and concern himself with the composition of the coins. Although the quantity of gold in gold coins can be approximated by determining the specific gravity, silver coins may be debased with varying amounts of lead so that the specific gravity measurements can be totally meaningless.

The elemental composition of probably no more than 1500 ancient and medieval coins have been reported in the literature. The reason is obvious; the analysis of the composition of a coin meant the destruction of an irreplaceable object. Even the use of small scrapings for spectroscopic studies has been limited because of the reluctance of curators and collectors to allow any permanent damage to the coins.

Neutron activation analysis, however, offers the possibility of making available to historians fundamental information about changes in the composition of coins without resorting to destructive analysis methods. Yet very little research on coins has been done using this technique. One of the most extensive studies using neutron activation analysis was performed at Oxford University where 5005 th century B.C. Greek silver coins were analysed for their copper and gold impurities (Emeleus 1958. Kraay 1959, Thompson 1960, Aitken et. al. 1962). Wyttenbach and Herman (1966) reported on the determination of the $\mathrm{Cu}$ and $\mathrm{Ag}$ contents of 400 15th century Swiss coins. Other studies include Norman and Suebic gold coins (Meloni and Maxia 1962), 3rd-8th century B.C. electrum coins from Lydia and Carthage (Das and Zonderhuis 1964, 1965), ancient Roman copper coins (Zuber 1966, Ravetz, 1963), 4th-6th century B.C. Greek silver coins (Bluyssen and Smith 1962), and recent Japanese silver coins (Kusaka 1959).

In the present study we have been concerned with the development of a rapid non-destructive method of analysis of the silver content of coins. We wished to base the analysis method on the short half-life isotopes of silver $\left({ }^{108} \mathrm{Ag}-2.4 \mathrm{~min}\right.$, ${ }^{110} \mathrm{Ag}-24 \mathrm{sec}$ ) and avoid producing appreciable amounts of the 270 -day ${ }^{110 \mathrm{~m}} \mathrm{Ag}$ isotope so that coins could be safely returned to their owners as soon as possible after performing the analysis. This requirement precluded the use of a nuclear reactor since the high neutron flux $\left(10^{12}\right.$ neutrons $\left.\mathrm{cm}^{-2} \mathrm{sec}^{-1}\right)$ would result in significant amounts of ${ }^{110 \mathrm{~m}} \mathrm{Ag}$ unless the irradiation was limited to about $10^{-6} \mathrm{sec}$ or the coins irradiated at a distance from the reactor where the flux was about 
$10^{-8}$ of that normally available in the usual irradiation positions. Physically, this latter possibility could pose problems in achieving reproducible positioning as well as rapid transfer of the coins from the reactor to the radioactivity detection equipment. Decreasing the irradiation duration to the time needed was impractical. An alternative irradiation procedure was used and the coins were irradiated instead using a $\mathrm{Pu}-\mathrm{Be}$ neutron source.

\section{NEUTRON SELF-SHADOWING EFFECTS}

The use of the Pu-Be neutron source solved the problem of obtaining a low neutron flux. However, two effects which would also exist in reactor irradiations were still present. The large neutron absorption cross-sections of silver can lead to neutron self-shadowing effects. In addition, the high-energy neutrons, upon passage through the coin, become degraded in energy. Both of these effects result in data which were dependent upon the thickness of the coin. For example, the specific activity of various $90 \%$ silver (pre-1965) U.S. coins were found to be 464 for a 10c. piece $(0.10 \mathrm{~cm}), 375$ for a $25 \mathrm{c}$. piece $(0.13 \mathrm{~cm}), 303$ for a $50 \mathrm{c}$. piece $(0.18 \mathrm{~cm})$. and 223 counts $/ \mathrm{gm}$ of silver for a silver $\$(0.23 \mathrm{~cm}$ thick). For coins of equal thickness the specific activity was dependent on the silver content, but not in any simple direct way. A method of irradiation was devised which permits determining the silver content in three ways, one of which is independent of the thickness of the coin.

\section{NEUTRON IRRADIATION}

All irradiations described below were performed by placing the coin and a silver disk or an uncirculated (pre 1965, 90\% silver) U.S. 10c. piece (taped to the back of the coin) about 1.5 inches from a 5 curie Pu-Be neutron source (figure 1)

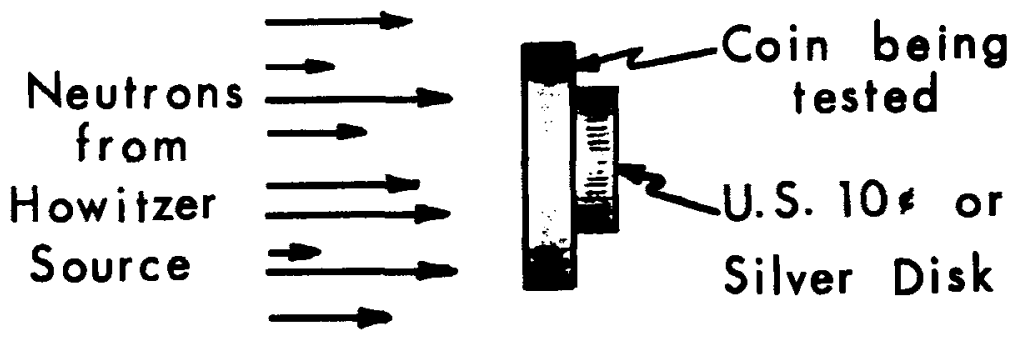

Fig. 1. The coin and a U.S. 10c. or silver disk taped to the coin are irradiated with neutrons.

housed in a paraffin-filled Howitzer (Nuclear Chicago Corp., Model NH 3). At this position the thermal neutron flux was approximately $4 \times 10^{4}$ neutrons $\mathrm{cm}^{-2}$ $\mathrm{sec}^{-1}$ when the 1.5 inch space was filled with paraffin. The high-energy flux at this position was not measured but should have been much less than the thermal flux. The coin and silver disk were irradiated for $1.00 \mathrm{~min}$. Under these conditions the only element present in a typical coin which would be sufficiently activated to be detected would be silver. No detectable amounts of the 270 -day ${ }^{110 m} \mathrm{Ag}$ were formed in the irradiation and only the $2.4 \mathrm{mir}-{ }^{108} \mathrm{Ag}$ and $24 \mathrm{sec}-{ }^{110} \mathrm{Ag}$ were detected. Because of the short half-lives of these isotopes it was possible to reirradiate a coin about 15 min after an irradiation and thus obtain a series of repeat analyses. 


\section{COUNTING PROCEDURE}

A 1.00 min count was taken on each coin starting $25 \mathrm{sec}$ after the end of the irradiation. The coin was counted using a 2 in $x$ 2in. NaI(TI) scintillation detector shielded by $1 \mathrm{~cm}$ of plastic to absorb beta radiation. The detector was coupled to a single-channel analyser with the detection level set so that all activity between 0.16 and $0.70 \mathrm{MeV}$ was recorded. Under these conditions very little of the beta activity of ${ }^{108} \mathrm{Ag}$ and ${ }^{110} \mathrm{Ag}$ was detected and essentially only decay gamma rays were recorded. Scintillation detection was chosen because it was possible to detect gamma-rays preferentially. If appreciable beta activity had been detected it would have been markedly dependent on the thickness of the coin because of beta-ray absorption within the coin. The silver disks or U.S. 10c. pieces were uniform in size and thickness and were counted by placing them $1 \mathrm{~cm}$ from a $3.2 \mathrm{mg} / \mathrm{cm}^{2}$ end-window beta counter. This type of detector was chosen since the background activity was approximately 50 times less than that recorded by the scintillation detector. Appreciable beta-ray self-absorption occurred in the disk or 10c. pieces, but the uniformity of these silver backing pieces assured that the fractional selfabsorption was constant in these two types of silver disks.

\section{SILVER ANALYSIS}

A number of modern U.S. and European coins of known silver contents (see Table I) were used in testing the validity of the methods of analysis. The data reported for these standards represent averages of 10 or more determinations.

\section{TABLE I}

\section{ANALYSIS OF THE SILVER CONTENTS OF MODERN COINS}

\begin{tabular}{|c|c|c|c|c|c|c|}
\hline \multicolumn{2}{|c|}{ Coin } & \multirow{2}{*}{$\begin{array}{c}\text { Thickness } \\
\mathrm{cm} .\end{array}$} & \multirow[t]{2}{*}{ Actual } & \multicolumn{2}{|c|}{$\begin{array}{l}\text { Percent Silver } \\
\quad \text { Experimentala }\end{array}$} & \multirow[b]{2}{*}{ Eq.3 } \\
\hline & & & & Eq.1 & $E q .2$ & \\
\hline \multirow{12}{*}{$\begin{array}{l}1961 \\
1961 \\
1945 \\
1967 \\
1922 \\
1930 \\
1929 \\
1925 \\
1944 \\
1951 \\
1886 \\
1964 \\
1964 \\
1964 \\
1908 \\
1944 \\
1882 \\
1918 \\
\text { Pure } \\
\text { Pure } \\
\text { Pure }\end{array}$} & $\begin{array}{l}\text { filed Mex. Peso } \\
\text { Mexican Peso }\end{array}$ & $\begin{array}{l}0.098 \\
0.198\end{array}$ & $\begin{array}{l}10.0 \\
10.0\end{array}$ & $\begin{array}{r}11.26 \\
9.76\end{array}$ & $\begin{array}{l}19.8 \\
23.7\end{array}$ & $\begin{array}{l}10.28 \\
10.25\end{array}$ \\
\hline & $\begin{array}{l}\text { U.S. } 5 c . \\
\text { U.S. } 50 \text { c. }\end{array}$ & $\begin{array}{l}0.173 \\
0.175\end{array}$ & $\begin{array}{l}35.0 \\
40.0\end{array}$ & 34.4 & $\begin{array}{l}33.1 \\
44.7\end{array}$ & $\begin{array}{l}33.4 \\
39.2\end{array}$ \\
\hline & filed British $\frac{1}{2} \mathrm{cr}$. & 0.097 & 50.0 & 52.8 & 37.0 & $\begin{array}{l}47.4 \\
48.8\end{array}$ \\
\hline & $\begin{array}{l}\text { British 6 pence } \\
\text { British florin }\end{array}$ & 0.196 & $\begin{array}{l}50.0 \\
50.0\end{array}$ & $\begin{array}{l}32.3 \\
42.8\end{array}$ & $\begin{array}{l}40.4 \\
53.7\end{array}$ & $\begin{array}{l}40.0 \\
49.0\end{array}$ \\
\hline & $\begin{array}{l}\text { Austrian shilling } \\
\text { Philippine } 20 \text { cent. }\end{array}$ & $\begin{array}{l}0.128 \\
0.124\end{array}$ & $\begin{array}{l}64.0 \\
75.0\end{array}$ & $\begin{array}{l}56.3 \\
76.0\end{array}$ & $\begin{array}{l}73.3 \\
65.3\end{array}$ & $\begin{array}{l}64.5 \\
73.8\end{array}$ \\
\hline & $\begin{array}{l}\text { Canadian 25c. } \\
\text { Swiss franc }\end{array}$ & $\begin{array}{l}0.142 \\
0.122\end{array}$ & $\begin{array}{l}80.0 \\
83.5\end{array}$ & $\begin{array}{l}76.7 \\
84.6\end{array}$ & $\begin{array}{l}70.5 \\
81.9\end{array}$ & $\begin{array}{l}79.4 \\
83.7\end{array}$ \\
\hline & filed U.S. $25 \mathrm{c}$. & $\begin{array}{l}0.051 \\
0.074\end{array}$ & $\begin{array}{l}90.0 \\
90.0\end{array}$ & $\begin{array}{l}86.9 \\
91.5\end{array}$ & $\begin{array}{l}107.5 \\
104.0\end{array}$ & $\begin{array}{l}88.6 \\
93.2\end{array}$ \\
\hline & $\begin{array}{l}\text { filed U.S. } 25 c \text {. } \\
\text { U.S. } 25 c \text {. }\end{array}$ & $\begin{array}{l}0.099 \\
0.127\end{array}$ & $\begin{array}{l}90.0 \\
90.0\end{array}$ & $\begin{array}{l}86.5 \\
90.8\end{array}$ & $\begin{array}{l}90.5 \\
89.0\end{array}$ & $\begin{array}{l}89.8 \\
93.2\end{array}$ \\
\hline & $\begin{array}{l}\text { U.S. } 50 \mathrm{c} . \\
\text { U.S. } \$ 1.00\end{array}$ & $\begin{array}{l}0.183 \\
0.234\end{array}$ & $\begin{array}{l}90.0 \\
90.0\end{array}$ & $\begin{array}{l}90.9 \\
83.0\end{array}$ & $\begin{array}{l}88.2 \\
93.8\end{array}$ & $\begin{array}{l}91.8 \\
92.1\end{array}$ \\
\hline & $\begin{array}{l}\text { Canadian } 25 c \text {. } \\
\text { silver } \\
\text { silver }\end{array}$ & $\begin{array}{l}0.130 \\
0.0084 \\
0.017\end{array}$ & $\begin{array}{r}92.5 \\
100.0 \\
100.0\end{array}$ & $\begin{array}{l}97.1 \\
70.8 \\
86.1\end{array}$ & $\begin{array}{l}81.4 \\
49.0 \\
62.1\end{array}$ & $\begin{array}{l}92.7 \\
63.9 \\
77.7\end{array}$ \\
\hline & & & & & & 87.3 \\
\hline & & Average $\%$ & Deviationb & $8.0 \%$ & $23.7 \% \mathrm{c}$ & $2.1 \%$ \\
\hline
\end{tabular}

- Experimental values based on average of 10 or more analyses.

b Pure silver data omitted in calculating \% deviation.

c Average $\%$ deviation $=12.0 \%$ if Mexican Peso data omitted. 
Method 1:

It might be expected that the logarithm of the activity per gram of silver in the coin would be proportional to the thickness of the coin, or more properly to the coin thickness times the silver percentage of the coin. However, a plot of the data according to this exponential relationship exhibited distinct curvature. A linear relationship provided a much more linear fit as seen in figure 2 .

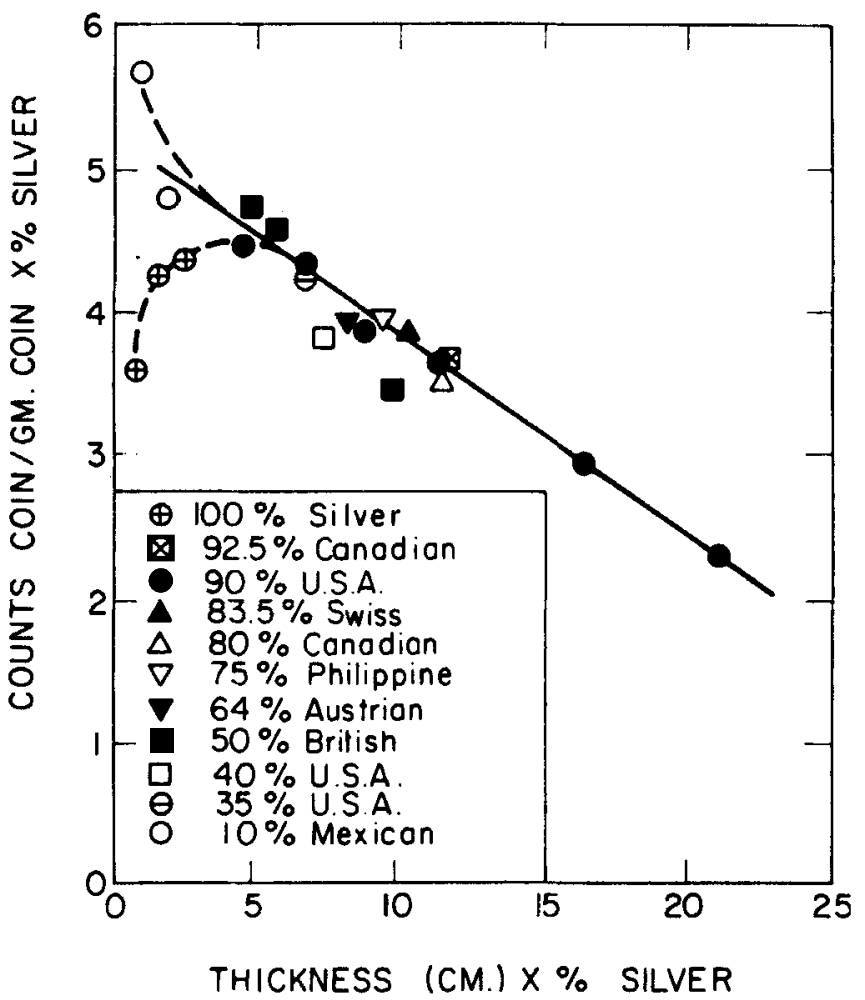

FIG. 2. Activity per gm. of silver in the coin as a function of thickness $\times \%$ silver of the coin. Each data point is an average of 5 or more determinations.

The relationship implied by the data of figure 2 involves a quadratic expression in the percent silver in the coin.

The equation is:

$$
\operatorname{AtmpP}^{2}-\mathrm{Bmp}+\mathrm{C}=0
$$

where $A$ and $B$ are constants determined from figure $2, t$ is the thickness, $m$ the mass of the coin, $\mathrm{P}$ the $\%$ silver, and $\mathrm{C}$ the activity.

This method of analysis is very similar to that described recently by Wyttenbach and Herman (1966).

Attempts to use equation 1 for the analysis of the silver content of coins resulted in calculated silver percentages that varied widely for repeat determinations on the same coin as seen in Table II. This difficulty arises not only from uncertainties in the fit given in figure 2 but also from the difficulty in measuring accurately the 
TABLE II

REPRODUCIBILITY OF REPEAT ANALYSES ${ }^{a}$

\begin{tabular}{|c|c|c|c|c|c|c|}
\hline $\begin{array}{l}\text { Counts } \\
\text { in coin }\end{array}$ & $\begin{array}{l}\text { Counts } \\
\text { in disk }\end{array}$ & & & $\begin{array}{r}\text { Basis } \\
\text { Method I }\end{array}$ & $\begin{array}{l}\text { for Calcul } \\
\text { Method } 2\end{array}$ & $\begin{array}{l}\text { ation } \\
\text { Method } 3\end{array}$ \\
\hline $\begin{array}{l}696 \\
657 \\
663 \\
734 \\
589 \\
573 \\
690\end{array}$ & $\begin{array}{r}300 \\
330 \\
323 \\
342 \\
274 \\
250 \\
301 \\
\text { Average. }\end{array}$ & $\begin{array}{l}\ldots \\
\cdots \\
\cdots \\
\cdots \\
\cdots \\
\cdots \\
\cdots\end{array}$ & $\begin{array}{l}\ldots \\
\cdots \\
\cdots \\
\cdots \\
\cdots \\
\cdots \\
\cdots\end{array}$ & $\begin{array}{r}120 \\
94 \\
110 \\
130 \\
91 \\
88 \\
120 \\
107 \pm 6\end{array}$ & $\begin{array}{r}57 \\
38 \\
42 \\
29 \\
77 \\
98 \\
57 \\
57 \pm 9\end{array}$ & $\begin{array}{r}94 \\
81 \\
83 \\
87 \\
87 \\
93 \\
93 \\
88^{ \pm}\end{array}$ \\
\hline
\end{tabular}

thickness of ancient and medieval coins. These coins frequently are very irregular in thickness and it is often difficult to measure the thickness to an accuracy better than $\pm 10 \%$.

Even the silver content of modern coins cannot be determined too accurately by this method. Using the straight line of figure 2 as a general calibration to obtain $A$ and $B$ in equation 1 each coin was treated as if its composition was unknown and the silver content calculated using equation 1 . These calculated percentages are given in Table 1. The average \% deviation in the calculated silver content was $8 \%$.

\section{Method 2:}

A simpler relationship is found if the coin to be examined is treated as an absorbing medium and the number of neutrons which penetrate through the coin determined. Rather than use a neutron detector to determine the neutron absorption of the coin we used instead standard silver disks taped to the back of the coin being irradiated. The larger the number of neutrons absorbed in the coin, the smaller the number of neutrons that reach the disk. The silver disks, therefore, can serve in a manner analagous to that of a photocell in a spectrophotometer and the activity induced in the silver disks would be directly proportional to the number of neutrons that penetrate through the coin. If the coins to be analysed were sufficiently large, U.S. 10c. pieces were used as the "photocell" disks. For smaller coins, a series of pure silver disks were used.

Data obtained with the use of the various standard coins are given in figure 3. The standard curve of figure 3 is easier to work with in determining the silver content of a coin than is the relationship given by equation 1 . The equation of ngure 3 is:

$$
\log \mathrm{I} / \mathrm{C}=-\mathrm{StP}
$$

where $\mathrm{I}$ is the extrapolated straight-line intercept and $\mathrm{S}$ the slope of figure 3, $\mathrm{C}$ the activity, $t$ the thickness, and $P$ the $\%$ silver.

Equation 2 still has one important disadvantage; the thickness of the unknown coin figures prominently in the calculation. Thus, the uncertainty in the calculated silver content would be directly related to the uncertainty in the measurement of the thickness of the coin as well as the uncertainty in the fit of the curve of figure 2 . Using values of $I$ and $S$ obtained from figure 3, values of $P$ were calculated for repeat determinations on a single coin (Table II). Calculated values of $P$ for the standards (Table I) also showed large errors, especially for the thinner coins and coins of lower silver content. 


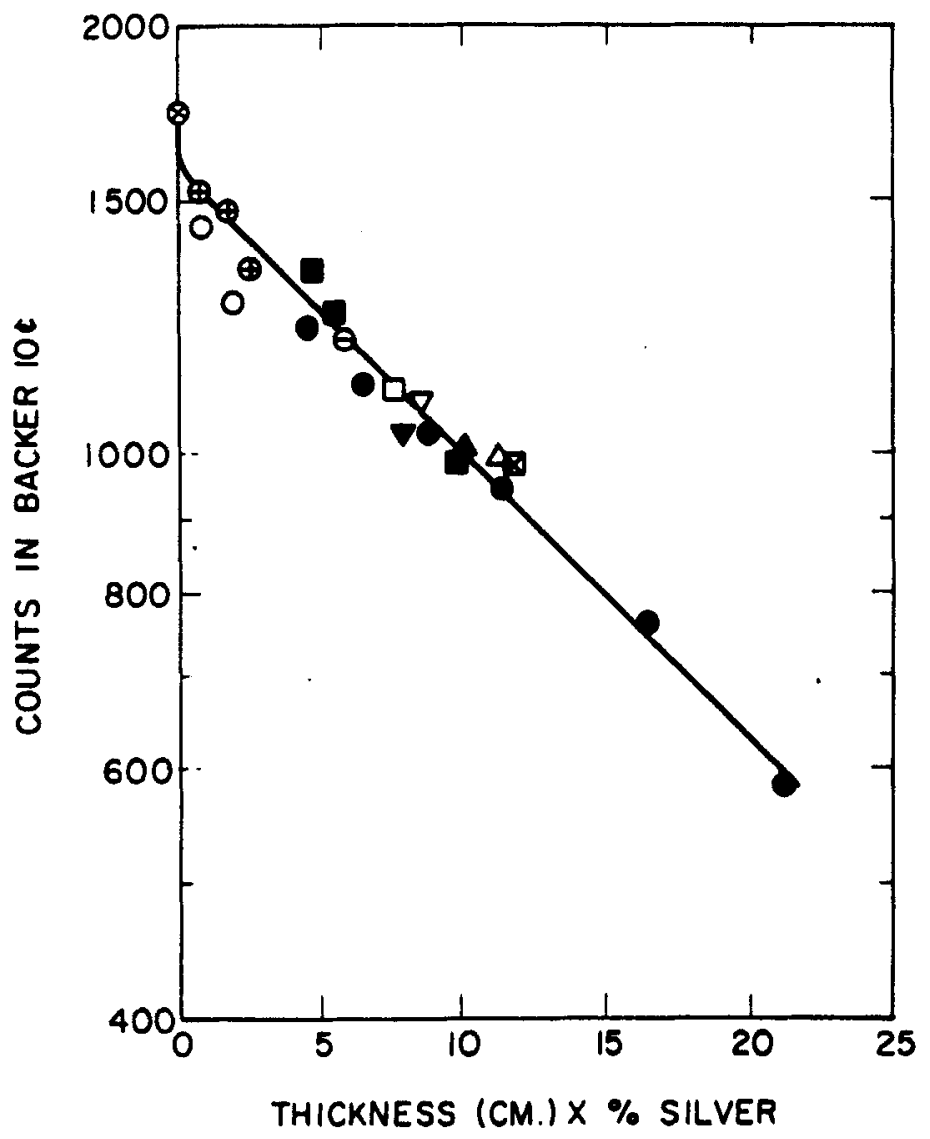

F10. 3. Activity in U.S. 10c. becker diaks a a function of the thicknes $\times \%$ silver of the front coin. Refor to figure 2 for identification of data. Point at zero thickness is for an unahielded 10c. disk.

\section{Method 3:}

However, an empirical relationship was found which was independent of the thickness of the coin over a wide range of thickneses. It was found that the ratio of the activity per gm. of coin per $\%$ silver divided by the activity in the silver backer disk was a constant as shown in figure 4 . Mathematically:

$$
P=C_{c} / C_{D} m E
$$

where $C_{C}$ and $C_{D}$ are the activities of the coin and disk (or 10c. piece), respectively, $m$ is the mass of the coin, $P$ the $\%$ silver in the coin, and $E$ the constant of figure 4.

The range over which this equation is valid encompasses the thicknewes of virtually all known ancient and medieval coins. A similar plot, which was a constant over the same thickness range, was found using the small silver disks. It is important to note that the data of figure 4 are plotted as a function of the coin thicknesses and not the coin thickness $x$ the $\%$ silver, is in figure 2 and 3 . Thus, the downward curvature at the left side of figure 4 is due to a thickness effect and not related to the silver content. If the silver content was important then the data 


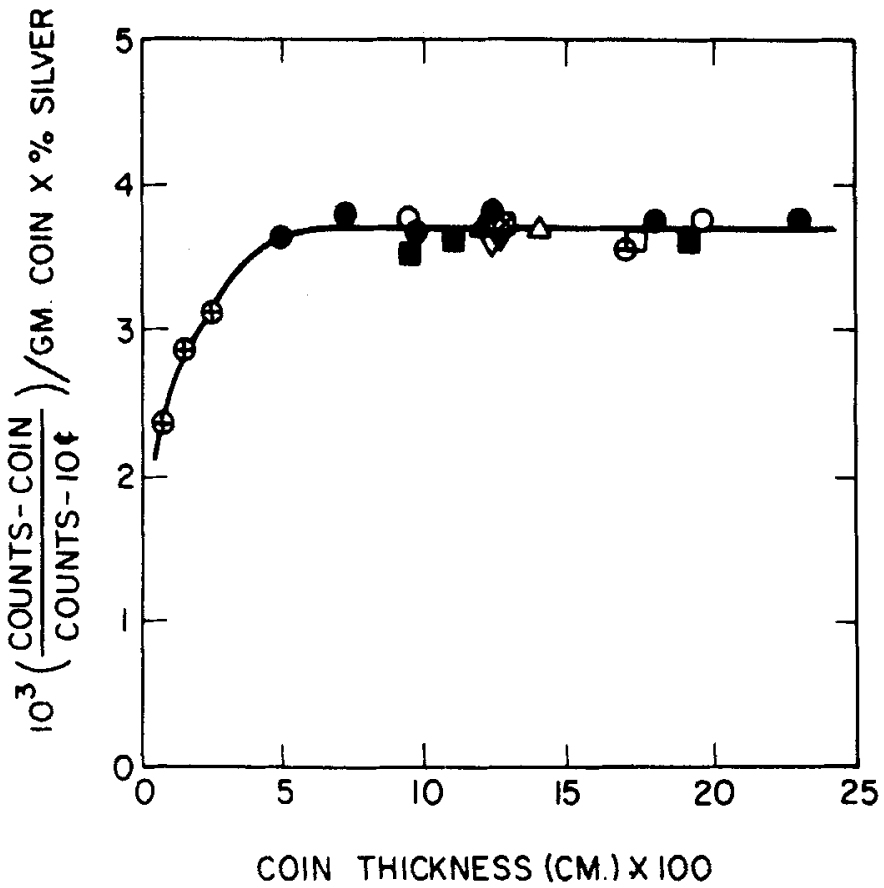

FIG. 4. Ratio of the activity par gram of silver in the coin to the activity in the 10c. backer disk as a function of the coin thickness. Data identification given in figure 2.

obtained for the $10 \%$ silver (Mexican) coins would have been numerically less. The ratio in the linear region $(0.05$ to $0.23 \mathrm{~cm})$ of figure 4 is $(3.71 \pm 0.02) \times 10^{-3}$. Using this value, it should be possible to determine the silver content of an unknown coin to with $\pm 0.5 \%$. However, this accuracy is not achicved in a single determination since the counting statistics are rather poor, particularly for the unknown coin. Thus, about five analyses were made for each coin and the calculated percentages averaged. These average data were typically within $\pm 2 \%$ of the actual silver content of the coins as in Table I. This accuracy is usually sufficient since ancient and medieval mints did not have "quality control" methods perfected to better than $\pm 2 \%$.

There are two reasons why determinations based on figure 4 should be more consistent than those based on figures 2 or 3. The first is the thickness independence of the ratio. The second is the (partial) cancellation of some systematic and random errors. Such errors could arise due to variations in positioning the coins during the irradiation and to slight variations in the timing of the irradiation or in beginning the one-minute count. Since these variations would be the same for both the coin and the backer disk the effects would tend to cancel and the ratio be more constant than the individual data for coin or backer disk. Using the value of the constant given in figure 4 , the silver contents of the standards were calculated (Table I) and found to have an average \% deviation of only $\pm 2.1 \%$.

An independent check of Method 3 was made using a series of Islamic coins for which the silver contents were also determined chemically. These coins were chosen for this analysis because they represented a set of "worst case" samples. 
These particular coins had thicknesses which were about $0.13 \mathrm{~cm}$. However, their diamsters were quite small (about $1 \mathrm{~cm}$ ) and the induced activity in each coin (about 500 counts) was relatively small compared with the background radiation of 1400 counts per min. The activities in the silver backing disks were about 300 counts compared with a background rate of 30 counts per min. Given in Table III

\section{TABLE III}

\section{COMPARISON OF SILVER CONTENTS}

\section{Coin}

U.S. 10c. Canadian $10 \mathrm{c}$

Islamic

Islamic

Islamic

Islamic
Percentage Silver Activation Chemical
Analysisa

$\begin{array}{cc}(90)^{b} & 89.9 \\ (80)^{b} & 80.2 \\ 86 \pm 2 & 87.7 \\ 89 \pm 2 & 93.1 \\ 93 \pm 2 & 93.5 \\ 91 \pm 2 & 92.1\end{array}$

a Based on Eq.3. Data are average of 5 or 6 analyses.

b Known silver content.

are data obtained for four such coins using the activation analysis method according to equation 3 and, afterwards, a destructive chemical silver analysis. As is seen from these data, the agreement between the two methods is generally within $\pm 2 \%$.

To date we have analysed over 800 coins using method 3. Data on Islamic coins from the Mamluk period have been reported by Bacharach and Gordus (1968). Representative data from this period are shown in figure 5. Other coins that were

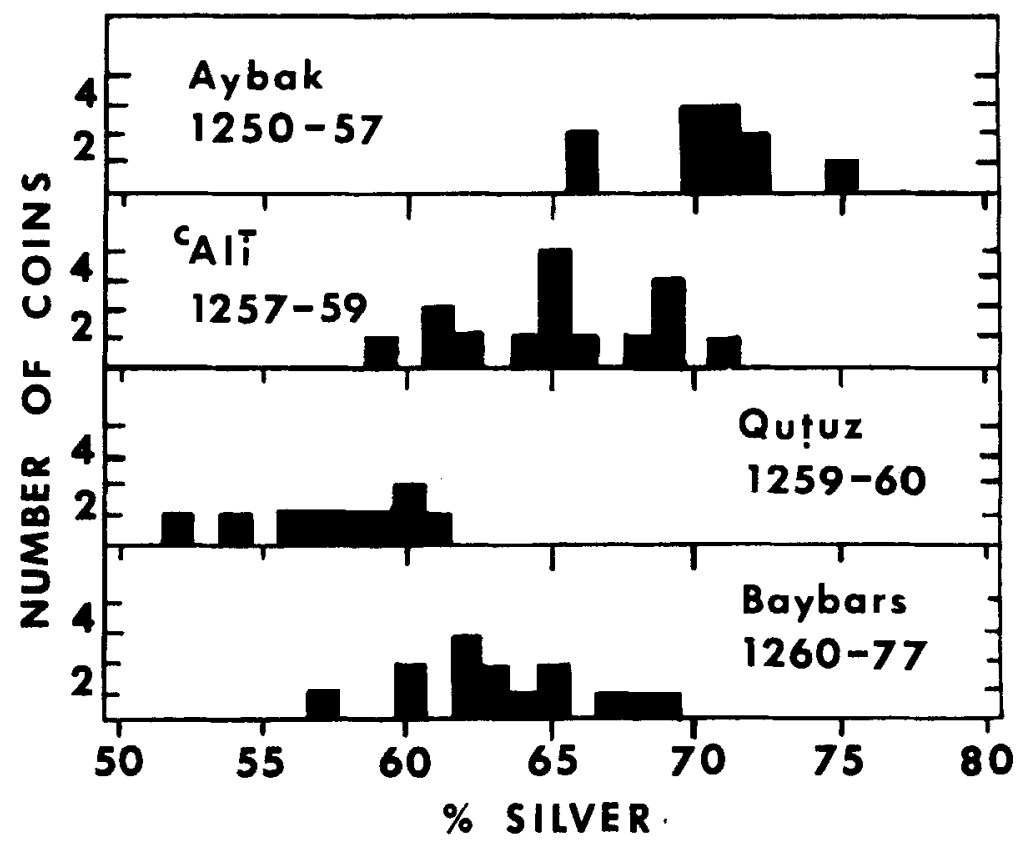

FIG. 5. Data obtained from the analysis of 49 Islamic coins from the period 1250-1277 A.D. 
analysed include Sasanian silver and potin (Bacharach and Gordus, in press), Frankish Greek coins, and a hoard of 198 Ilkhanid dirhems of Uljaitu. In addition, the silver contents of a few gold and copper coins were also determined using method 3, which, it should be noted, is equally applicable to these types of coins.

\section{ACKNOWLEDGEMENTS}

Prof. Jere Bacharach originally suggested to the author the need for a simple non-destructive method of silver analysis. He provided many of his own coins for analysis and contributed the specimens that were destroyed for the chemical analyses. Dr. G. C. Miles of the American Numismatic Society arranged for the loan of Islamic and Sasanian coins and Prof. D. M. Metcalf of the Ashmo'ean Museum lent Frankish Greek coins. John Secrist, Barry Bateman, and Glenn Woodsum, Honors undergraduates at The University of Michigan, assisted in developing the methods and performing the analyses. This study was supported by a grant from the University of Michigan-Memorial Phoenix Project and by the U.S. Atomic Energy Commission, Division of Research.

\section{REFERENCES}

Aitken, M. J., Emeleus, V. M., Hall, E. T., and Krazy, C. M., 1962, "Conf. Radioisotopes in the Physical Sciences and Industry",11, 263, Intl. Atomic Energy Agency, Vienna.

Bacharach, J. and Gordus, A. A., 1968, J. Econ. Soc. Hist. Orient, to be published.

Bacharach, J. and Gondus, A. A., J. Am. Oriental Soc., in press.

Bluyssen, H. and Smith PH. B., 1962, Archaeometry, 5, 113.

Das, H. A. and Zonderhuis, J., 1964, Archaeometry, 7, 90.

Das, H. A. and Zonderhuis, J., 1965, Chem. Weekblad, 61 (18), 215.

Emeleus, V. M., 1958, Archaeometry, 1, 6.

Kraay, C. M., 1959, Archaeometry, 2, 1.

Kusaka, Y., 1959, Japan Analyst, 8, 111.

Meloni, S. and Maxia, V., 1962, Guzz. Chim. Ital., 92, 1432.

Ravetz, A., 1963, Archaeometry, 6, 46.

Thompson, M., 1960, Archaeometry, 3, 10.

Wyttenbach, A. and Hermann, H., 1966, Archaeometry, 9, 139.

Zuber. I. K., 1965, 1966, At. Energy Comm., Istanbul, Report No. CNAEM-21, part 1 (1965), CNAEM-35, part 2 (1966). 